\title{
AHOK DALAM BERITA MAYA
}

\author{
Novian Anata Putra \\ Balai Pengkajian dan Pengembangan Komunikasi dan Informatika (BPPKI) Yogyakarta \\ J1. Imogiri Barat Km.5 Sewon, Bantul, DI.Yogyakarta. Telp. (0274)375253 Fax. (0274)375253 \\ Email: noviananata@gmail.com
}

Naskah diterima tanggal 16 Februari 2014, direvisi tanggal 26 Mei 2015, disetujui tanggal 4 November 2015

\section{AHOK IN VIRTUAL NEWS}

\begin{abstract}
Every society is flooded by Information in the Internet era. News sites as one of the sources of information are now numerous. However, do these bits of information worth to be trusted fully? Through quantitative content analysis, the researcher tried to examine one of the news sites based on religion (Islamic hardliners), VOA-Islam, in reporting Basuki Tjahaja Purnama a.k.a Ahok, which incidentally is a non-Muslim Chinese descent. Using Jurgen Westerstahl's objectivity approach (1983), found the fact that the news presented by VOA-Islam does not contain elements of balance, even most of it shows a negative tendency, cornered Ahok as a central figure in DKI Jakarta. In fact, from the dimensions of relevance, the percentage of news from VOA-Islam, which has a significant effect to the activity of community life and proximity to the topic of the public, are quite high. In addition to the large amount of news that contains racial issues, it becomes worrisome because it could lead to the disintegration of the nation.
\end{abstract}

Keywords: content analysis, news, online, VOA-Islam.

\begin{abstract}
Abstrak
Informasi membanjiri media di setiap penjuru masyarakat. Situs berita sebagai salah satu sumber informasi saat ini sudah banyak jumlahnya. Namun apakah semua informasi ini layak untuk dipercaya sepenuhnya. Melalui analisis isi kuantitatif peneliti mencoba membedah salah satu situs berita berlandaskan agama (Islam garis keras), VOA-Islam, dalam memberitakan Basuki Tjahaja Purnama alias Ahok yang notabene merupakan keturunan Tionghoa non Muslim. Dengan pendekatan objektivitas dari Jurgen Westerstahl (1983) ditemukan fakta bahwa berita yang disajikan VOA-Islam tidak mengandung unsur keberimbangan, bahkan sebagian besar bertendensi negatif, memojokkan Ahok sebagai tokoh penting di DKI Jakarta. Padahal dari dimensi relevansi, persentase berita dari VOA-Islam yang memiliki signifikansi memengaruhi aktivitas hidup masyarakat dan kedekatan topik dengan masyarakat cukup tinggi. Ditambah lagi dengan tingginya persentase jumlah berita yang bermuatan isu SARA, semakin mengkhawatirkan karena dapat memicu perpecahan bangsa.
\end{abstract}

Kata kunci: analisis isi, berita, online, VOA-Islam. 


\section{PENDAHULUAN}

Dunia maya saat ini seperti angkasa luas tempat milyaran informasi bertebaran. Jika tidak berhati-hati memeriksa setiap informasi yang ditemui, masyarakat akan mudah tersesat di dalamnya. Memeriksa, memeriksa, dan memeriksa kembali setiap informasi yang diperoleh dari internet akan menyelamatkan seseorang dari ketersesatan (Kovach dan Rosenstiel, 2011). Tren berita jadi-jadian dan fitnah yang bertebaran di internet semakin menjadi akhir-akhir ini, apalagi setelah pemilu legislatif usai dan konsentrasi rakyat beralih kepada Pemilihan Presiden periode 2014-2019. Sasarannya pun beragam, mulai dari partai politik, pasangan yang maju sebagai calon presiden bahkan sampai kepada keluarga calon pasangan presiden. Isu yang diangkat pun tak kalah banyak macamnya, dari korupsi, HAM, terorisme, sampai kepada isu-isu sensitif bernuansa SARA. Sayangnya, tidak sedikit masyarakat yang percaya begitu saja dan bahkan ikut menyebarkan fitnah itu melalui akun pribadinya.

Sudah tidak sulit lagi ditemukan berita yang mencampur-adukkan antara fakta dan fitnah. Berita tersebut lalu lalang di berbagai media seperti twitter, facebook, website, atau bahkan layanan pesan pendek seperti whatsapp dan BlackBerry Messenger (BBM). Dalam masa Pemilu 2014 ini, akun twitter @Triomacan2000, website pkspiyungan.org, portal berita VOA-Islam dan Arrahmah.com meraih puncak ketenarannya dalam hal menebar informasi tentang pemilu. Informasi tersebut kemudian ikut disebarluaskan oleh jutaan pendukung peserta pemilu yang diuntungkan dari pemberitaan tersebut. Padahal, tidak semua informasi tersebut bisa dipertanggungjawabkan, sebagian besar hanya informasi sampah dan bualan belaka, bahkan cenderung menjadi fitnah. Hal ini semata-mata untuk saling menjatuhkan lawan politiknya.

Selain kepada lawan politik, tak sedikit pula berita-berita sesat yang beredar ini menyerang kelompok minoritas ketika berbicara tentang SARA. Perlu diketahui bahwa perbincangan tentang SARA awalnya adalah perbincangan yang sangat sensitif di Indonesia. Namun, seiring perkembangannya, kaum aliran garis keras tak sungkan mengatas namakan suku, ras, dan agamanya untuk menyerang kaum yang berbeda aliran. Tidak heran jika di Indonesia sering muncul perpecahan berlatarbelakang SARA.

Salah satu yang menonjol dalam pemberitaan beraroma SARA adalah pemberitaan tentang Wakil Gubernur DKI Jakarta Basuki Tjahaja Purnama ketika diberitakan oleh media Islam garis keras seperti VOA-Islam. Sosok yang memiliki nama Tionghoa: Zhōng Wànxué dan dikenal dengan panggilan akrab Ahok ini adalah Gubernur DKI Jakarta yang menjabat sejak 19 November 2014. Ia merupakan etnis Cina pertama dan orang Kristen Protestan pertama yang mengemban jabatan tersebut. Pemberitaannya di VOA-Islam selalu menonjol karena pemberitaan tentang Ahok yang notabene warga Cina, selalu dikaitkan dengan suku, ras, dan agamanya, apapun topik beritanya. Sikap politik Ahok memang sudah menjadi sorotan di berbagai media. Gaya kepemimpinannya yang keras dan berbeda menjadikan Ahok sosok kepala daerah yang kontroversial. Keputusanya keluar dari Gerindra, partai pengusungnya di DKI Jakarta, karena perbedaan pendapat pada RUU Pilkada hingga usaha kerasnya membubarkan Ormas FPI (Front Pembela Islam) tak luput dari liputan media.

Itulah sebagian kecil contoh fenomena yang sedang terjadi dalam media pemberitaan online garis keras di Indonesia. Kebebasan dalam pemberitaan media online sudah tak lagi peduli apakah beritanya akan berdampak buruk bagi hubungan antar umat beragama atau tidak. Isu-isu negatif yang berhubungan secara langsung maupun tidak langsung dengan suku, ras, dan agama tertentu selalu dijadikan bahan pro-kontra. Sebagian masyarakat pun juga ikut berperan memperburuk keadaan ini. Kurangnya pengetahuan masyarakat tentang sifat media online dianggap juga sebagai penyebabnya. Tanpa berusaha mencari klarifikasi kebenaran dari berita yang dibacanya, sebagian 
masyarakat ikut serta menyebarluaskan berita-berita ini melalui akun pribadinya di dunia maya. Melihat situasi semacam ini, Kementerian Komunikasi dan Informatika masih dianggap lemah melihat fenomena tersebut. Melalui penelitian ini, penulis ingin memerlihatkan gambaran secara ilmiah tentang fenomena portal berita garis keras seperti VOA-Islam.

\section{LANDASAN KONSEP}

\section{Media Massa dan Berita}

Media massa seperti yang dikemukakan oleh Althusser dan Gramsci dalam Sobur (2004) merupakan alat yang digunakan untuk menyampaikan pendapat atau aspirasi baik itu dari pihak masyarakat maupun dari pihak pemerintah atau negara. Media massa memunyai kekuatan yang sangat signifikan dalam usaha memengaruhi khalayaknya. Media massa tidak bisa dilepaskan dengan berita. Menurut McQuail (1989) berita merupakan sesuatu yang bersifat metafisik dan sukar dijawab kembali dalam kaitannya dengan institusi dan kata putus mereka yang bersifat rasa dan sulit diraba karena kehalusannya. Suatu fakta dapat dikatakan berita, apabila memenuhi syarat antara lain telah dipublikasikan oleh seseorang atau institusi yang jelas identitasnya, alamat, dan penanggungjawabnya, fakta tersebut ditemukan oleh jurnalis dengan cara yang sesuai dengan standar operasional dan prosedur dalam profesi jurnalistik (Panuju, 2005). Dari beberapa definisi tersebut dapat dirangkum bahwa berita adalah laporan dari kejadian yang penting atau peristiwa hangat, dapat menarik minat atau perhatian para pembaca.

Menurut Djuroto (2002) untuk membuat berita paling tidak harus memenuhi beberapa persyaratan, antara lain menjaga objektivitas dalam pemberitaan, faktanya tidak boleh diputar sedemikian rupa hingga tinggal sebagian saja, dan yang terakhir berita itu harus menceritakan segala aspek secara lengkap. Sedangkan menurut Kusumaningrat (2007) unsur-unsur yang membuat suatu berita layak untuk dimuat ada tujuh yaitu; akurat, lengkap, adil, berimbang, objektif, ringkas, jelas, dan hangat. Selain unsur-unsur berita, wartawan juga harus memikirkan nilai berita yang ingin disampaikan kepada pembacanya. Nilai berita ini menjadi penentu berita layak diberitakan. Menurut Ishwara (2005) peristiwa-peristiwa yang memiliki nilai berita ini misalnya yang mengandung konflik, bencana, dampak, kemasyhuran, segar, dan kedekatan, keganjilan, human interest, seks, dan aneka nilai lainnya. Dalam kacamata jurnalistik, tidak semua fakta adalah berita. Suatu fakta dapat dikatakan berita, apabila memenuhi syarat antara lain telah dipublikasikan oleh seseorang atau institusi yang jelas identitasnya. Fakta tersebut dihimpun oleh jurnalis dengan cara yang sesuai dengan standar operasional dan prosedur dalam profesi jurnalistik (Sumadiria, 2005).

\section{Jurnalisme Online sebagai Media Massa}

Munculnya jurnalisme online mungkin tidak akan bisa menggantikan sepenuhnya bentuk-bentuk media lama. Melainkan menciptakan suatu cara yang unik untuk memroduksi berita dan mendapatkan konsumen berita. Jurnalisme online tidak akan menghapuskan jurnalisme tradisional, namun meningkatkan intensitasnya. Dengan menggabungkan fungsi-fungsi dari teknologi internet dengan media tradisional (Santana, 2005).

Teori konvergensi menyatakan bahwa berbagai perkembangan bentuk media massa terus merentang sejak awal siklus penemuannya. Setiap model media terbaru tersebut cenderung merupakan perpanjangan atau evolusi, dari model-model terdahulu. Dalam konteks ini, internet bukanlah suatu pengecualian (Stovall, 2005). Dalam masyarakat modern, media memainkan peran penting untuk perkembangan politik masyarakatnya. Kebebasan berekspresi menyampaikan informasi merupakan dasar penting untuk sistem demokratis dan telah dikukuhkan dalam semua dokumen hak asasi manusia yang dikeluarkan setelah perang dunia kedua (Sobur, 2004). 
Foust (2009) memperkenalkan praktik jurnalisme online dengan menjelaskan praktik jurnalisme tradisional. Mengutip jurnalis awal abad 20an, Finley Peter Dunne, Foust menulis bahwa tujuan jurnalisme adalah "to comfort the afflicted and afflict the comfortable" yang artinya menghibur mereka yang dirundung masalah dan memberi masalah pada mereka yang hidup nyaman. Demi berlangsungnya demokrasi, masyarakat memerlukan informasi mengenai berbagai isu yang memengaruhi hidup mereka.

Jurnalisme online dianggap juga sebagai tipe baru jurnalisme karena memiliki sejumlah fitur dan karakteristik yang berbeda dari jurnalisme tradisional. Fitur-fitur uniknya mengemuka dalam teknologinya, menawarkan kemungkinan-kemungkinan tidak terbatas dalam memroses dan meyebarkan berita (Santana, 2005). J.Pavlik (2001) menyebut tipe baru jurnalisme ini sebagai contextualized journalism, karena mengintegrasikan tiga fitur komunikasi yang unik, yaitu kemampuan-kemampuan berdasarkan platform digital, kualitas interaktif komunikasi online, dan fitur-fitur yang ditatanya (costumizeable features).

Jurnalis sebagai pengumpul dan penyedia informasi memiliki keunikan dibandingkan pekerjaan penulis lainnya. Keunikan yang juga membedakan situs jurnalisme dari situs lainnya: fairness, attribution, accuracy, relevance dan newness (Foust, 2009). Selalu ada kecenderungan bias, baik pada jurnalisme tradisional maupun online. Pernyataan ini membuat peneliti ingin melihat sejauhmana bias-bias tersebut dapat terlihat di pemberitaan situs berita online Islam garis keras, VOA-Islam.

\section{Objektivitas Berita}

$\begin{array}{cccc}\text { Menurut DeFleur dalam } & \text { McQuail } \\ \text { (1994) } & \text { Pers } & \text { senantiasa } & \text { dituntut }\end{array}$ mengembangkan pemberitaan yang objektif, yaitu "reporting format that generally spates fact from pinion present an emotionally detached view of the news, and strives for fairness and balanced."

Dalam jurnalisme, kebenaran tidaklah bisa diklaim oleh satu pihak, namun harus dikonfirmasikan menurut kebenaran dari pihak lain. Inilah mengapa pemberitaan di surat kabar selalu dituntut untuk mengungkapkan kebenaran secara fairness. Hal tersebut merupakan salah satu syarat objektivitas yang juga sering disebut sebagai pemberitaan cover both side, yaitu pers menyajikan informasi dari semua pihak yang terlibat sehingga pers mempermudah pembaca menemukan kebenaran. Selain fairness, pers juga dituntut melakukan pemberitaan yang akurat, tidak bohong, menyatakan fakta bila itu memang fakta, dan pendapat bila itu memang pendapat, dikutip dari Siebert tahun 1986 (Bungin, 2006).

Jurgen Westerstahl menjabarkan konsep objektivitas pada gambar 1 (1983). Westerstahl mengajukan komponen utama objektivitas berita dalam observasinya maintaining objectivity in the dissemination of news can, it seems to me, most easily be defined as adherence to certain norm or standards (1983). Berdasarkan skema gambar 1, objektivitas diturunkan menjadi dua konsep

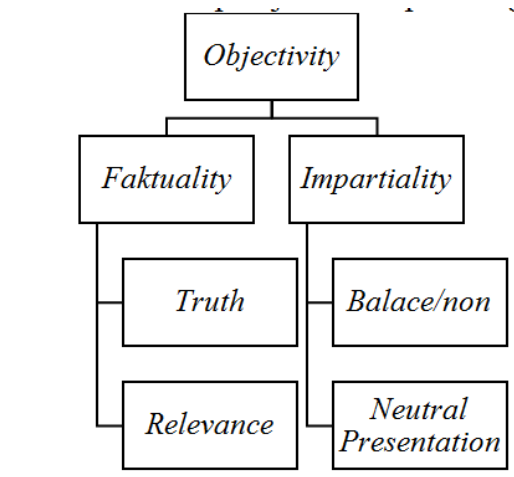

Gambar 1

Konsep Objektivitas Westerstahl 
yaitu faktualitas dan imparsialitas atau ketidakberpihakan. Dimensi dalam penelitian ini adalah keberimbangan (balance) yang diturunkan dari imparsialitas dan relevansi (relevance) yang diturunkan dari faktualitas.

Penelitian ini mengerucut pada konsep keberimbangan (balance) dan relevansi (relevance). Untuk melihat keberimbangan dan relevansi, peneliti menggunakan poinpoin yang diambil dari definisi McQuail yang sudah dijelaskan secara singkat dalam kerangka teori. Selain itu peneliti juga menggunakan beberapa poin dari panduan yang dibuat Krippendorff untuk membuat kategorisasi dengan beranjak dari what dan how, seperti direction dan value (Krippendorff dalam Prajarto 2010).

Poin-poin berikut akan digunakan untuk untuk menentukan unit klasifikasi keberimbangan: 1. Sumber berita. Poin ini digunakan peneliti untuk melihat dari mana atau siapa sumber berita yang digunakan dalam suatu pemberitaan, apakah hanya ada satu sumber berita atau lebih dari satu; 2 . Proporsi penyajian sumber berita. Poin ini digunakan untuk melihat apakah jurnalis menyajikan sisi-sisi cerita dari sumber berita dengan porsi yang sama atau malah tidak ada sama sekali. Proporsi ini dapat dilihat dari banyaknya paragraf yang menyajikan sisi cerita; 3. Sudut pandang. Dengan poin ini peneliti melihat apakah ada sudut pandang tertentu yang direfleksikan dari sebuah pemberitaan. Jika sebuah berita merujuk pada suatu kejadian yang telah terjadi atau sedang terjadi, kemudian menawarkan suatu sudut pandang berbeda mengenai kejadian tersebut, berarti ada sudut pandang baru yang ditawarkan kepada khalayak.

Evaluative tendency. Poin ini sebagai dasar untuk melihat arah kecenderungan pemberitaannya negatif, positif, atau netral. Pada dasarnya peneliti menggunakan konsep ini untuk melihat kecenderungan pemberitaan dalam kesatuan item-item berita, sejauhmana media berusaha mengangkat sisi positif dan negatif sebuah topik melalui berita-beritanya.

Sedangkan untuk melihat relevansi, peneliti mengombinasikan definisi secara teori yang dipaparkan McQuail dan definisi yang dikutip dari Burgoon. 1. Signifikansi. Mengambil pengertian signifikansi yang dipaparkan McQuail dan Burgoon seperti tertulis dalam kerangka teori, signifikansi berita di sini diukur dengan melihat apakah informasi yang diberitakan ada pengaruhnya bagi orang banyak atau tidak; 2 . Kontribusi. Poin ini menjadi dasar untuk melihat apakah informasi dalam berita tersebut memiliki kontribusi dalam menambah pengetahuan atau wawasan masyarakat ataukah informasi tersebut hanya bersifat hiburan atau trivia; 3 . Kedekatan topik. Menurut Burgoon berita memiliki relevansi jika menceritakan sesuatu yang dekat dengan kehidupan masyarakat. Peneliti menggunakan poin ini untuk melihat apakah topik berita berhubungan dekat dengan kehidupan dan aktivitas masyarakat umum atau semata-mata ada hubungan dengan isu besarnya saja yaitu kampanye parpol, tapi tidak menyentuh sisi kehidupan masyarakat.

Selain itu peneliti juga ingin melihat konten SARA (Suku, Agama, Ras, dan Antargolongan) pada berita yang diposting dalam situs berita Islam garis keras ini. Dengan melihat adakah konten berita yang mengandung isu sensitif ini, peneliti akan menggunakannya untuk melengkapi sekaligus mempertegas analisis dalam melihat gambaran berisikonya situs berita ini dalam kehidupan masyarakat yang plural di Indonesia.

\section{METODE PENELITIAN}

Metode penelitian yang digunakan dalam penelitian ini adalah metode analisis isi. Kriyantono (2006) mengemukakan bahwa metode analisis isi adalah metode yang digunakan untuk meriset atau menganalisis isi komunikasi secara sistematik, objektif, dan kuantitatif. Kaitannya dengan riset ini, adalah untuk mendeskripsikan posisi portal berita Islam garis keras, VOA-Islam, dalam memberitakan gubernur DKI Jakarta, Ahok.

Dalam menentukan populasi, peneliti mengambil semua berita dalam situs berita 
VOA-Islam yang khusus memberitakan Ahok

dan tersedia pada pencarian pada tanggal 30

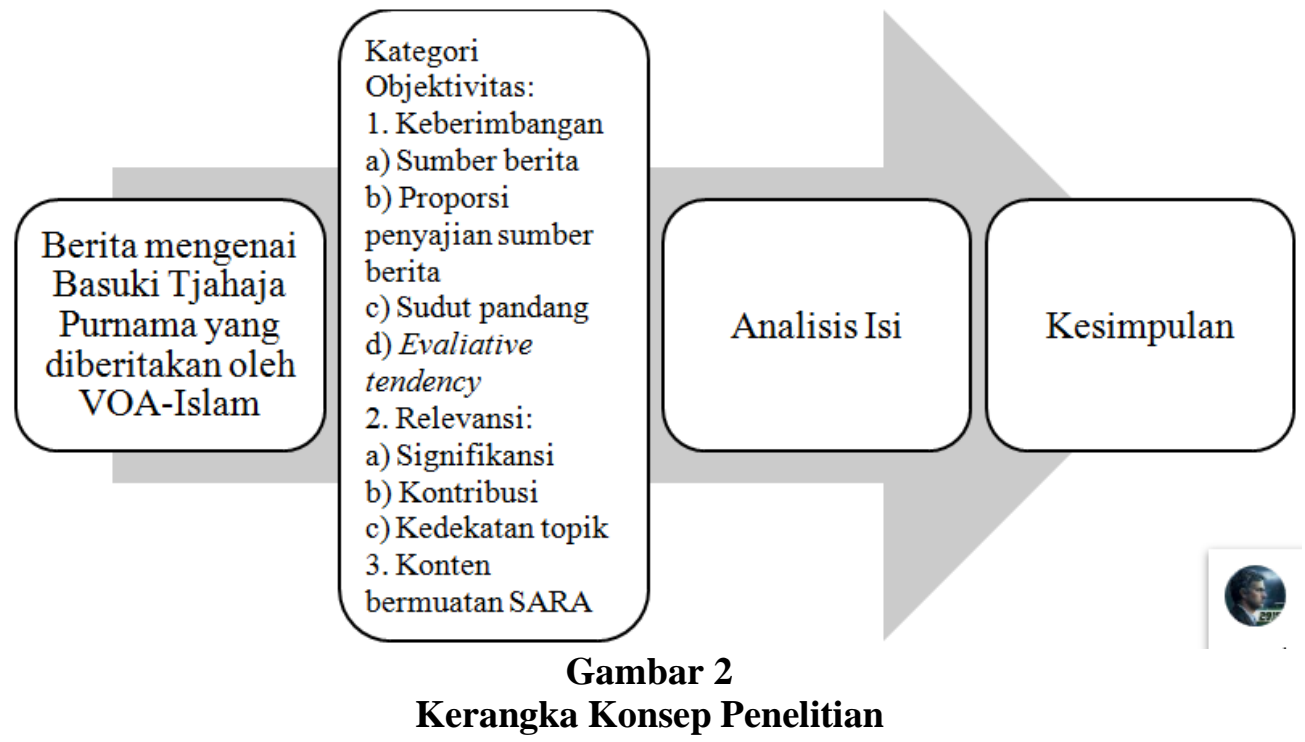

Oktober 2014. Tidak terdapat penentuan sampel namun akan mengambil seluruh populasi dikarenakan semua berita yang tersedia tersebut bersifat penting dalam penelitian yang akan di lakukan.

Proses penjaringan seluruh berita untuk memeroleh berita yang spesifik memberitakan tentang Ahok dalam penelitian ini menggunakan mesin pencari (search engine) tunggal yang disediakan di situs berita VOA-Islam. Prosedur serupa pernah digunakan pada penelitian Anselmo et al (2004) dalam (Snelson, 2005) yang menggunakan mesin pencari (search engine) tunggal untuk meneliti informasi fibrosis kistik yang ditemukan di web, serta penelitian Pitoyo (2007) yang menganalisis isi situs web tanggap bencana alam gempa bumi D.I. Yogyakarta dan Jawa Tengah.

Dalam menentukan populasi dalam penelitian ini, peneliti melakukan beberapa tahapan untuk menentukan berita-berita yang khusus memberitakan tentang Ahok. Pertama peneliti menggunakan kata kunci "Ahok" dan "Basuki Tjahaja Purnama" dalam pencarian berita ini. Peneliti mendapatkan 100 berita dengan kata kunci tersebut. Di antara semua berita tersebut, ada 5 (lima) berita yang sama baik judul maupun isinya. Peneliti langsung melakukan eliminasi terhadap 5 (lima) berita tersebut. Karena peneliti hanya ingin mencari berita-berita yang menjadikan ahok sebagai objek beritanya, peneliti mengeliminasi

kembali berita-berita dari 95 berita tersebut yang tidak menggunakan kata "Ahok" maupun "Basuki Tjahaja Purnama" dalam judulnya. Hasilnya, terdapat 11 berita yang tidak menjadikan kata "Ahok" dan "Basuki Tjahaja Purnama" dalam judul. Kemudian dari hasil 84 berita tersebut dipersempit lagi dengan membaca dan memilih berita yang menjadikan sosok Ahok menjadi satu-satunya objek dalam beritanya. Hal ini dikarenakan dari berita tersebut banyak di antaranya tidak membahas ahok secara khusus, seperti pembahasan tentang Jokowi-Ahok ataupun Ahok dengan tokoh lain. Hasilnya ada 54 berita yang spesifik membahas Ahok. Beritaberita inilah yang akan menjadi populasi dalam penelitian kali ini. Pengumpulan data dilakukan dengan melalui coding sheet. Sebelum mengolah dan menganalisis data, peneliti akan menggunakan uji reliabilitas antarkoder yang akan dilakukan untuk 2 orang coder, dengan menggunakan rumus dalam bentuk formula untuk koefisien

$$
\mathrm{CR}=\frac{2 \mathrm{M}}{\mathrm{N} 1+\mathrm{N} 2}
$$

reliabilitas seperti yang dijelaskan dalam Prajarto (2010), yaitu:

$\mathrm{CR}=$ koefisien reliabilitas

$\mathrm{m} \quad=$ jumlah pernyataan yang disetujui kedua coder

$\mathrm{N} 1, \mathrm{~N} 2=$ jumlah pernyataan yang dikode oleh coder pertama dan kedua 
Pada tahap awal peneliti melakukan uji reliabilitas antarkoder (intercoder reliability) yang dilakukan oleh 2 orang coder. Dalam uji reliabilitas ini, 2 coder melakukan coding terhadap 25 berita dari situs berita VOAIslam. Dari uji reliabilitas ini didapatkan hasil sebagai berikut:

- Sumber Berita

$\mathrm{CR}=\frac{2 \mathrm{M}}{\mathrm{N} 1+\mathrm{N} 2}=\frac{2(22)}{25+25}=\frac{44}{50}=0.88$

- Proporsi penyajian sumber berita

$\mathrm{CR}=\frac{2 \mathrm{M}}{\mathrm{N} 1+\mathrm{N} 2}=\frac{2(20)}{25+25}=\frac{40}{50}=0.80$

- $\quad$ Sudut pandang

$\mathrm{CR}=\frac{2 \mathrm{M}}{\mathrm{N} 1+\mathrm{N} 2}=\frac{2(24)}{25+25}=\frac{48}{50}=0.96$

- Evaluating tendency

$\mathrm{CR}=\frac{2 \mathrm{M}}{\mathrm{N} 1+\mathrm{N} 2}=\frac{2(22)}{25+25}=\frac{44}{50}=0.88$

- Signifikansi

$\mathrm{CR}=\frac{2 \mathrm{M}}{\mathrm{N} 1+\mathrm{N} 2}=\frac{2(19)}{25+25}=\frac{38}{50}=0.76$

- Kontribusi

$\mathrm{CR}=\frac{2 \mathrm{M}}{\mathrm{N} 1+\mathrm{N} 2}=\frac{2(19)}{25+25}=\frac{38}{50}=0.76$

- Kedekatan topik

$\mathrm{CR}=\frac{2 \mathrm{M}}{\mathrm{N} 1+\mathrm{N} 2}=\frac{2(17)}{25+25}=\frac{34}{50}=0.68$

- Konten SARA

$\mathrm{CR}=\frac{2 \mathrm{M}}{\mathrm{N} 1+\mathrm{N} 2}=\frac{2(24)}{25+25}=\frac{48}{50}=0.96$

Melihat hasil uji realibilitas di atas, sebagian besar memiliki nilai cukup tinggi yang bisa dikatakan reliabel. Hanya satu yang memiliki nilai di bawah 0,75 , namun karena masih dianggap di atas dari separuh $(0,50)$ maka kategori ini tetap diikutkan dengan perbaikan panduan pengisian coding sheet.

\section{HASIL PENELITIAN DAN PEMBAHASAN}

\section{Keberimbangan (Balance)}

Dalam objektivitas, imparsialitas yang terkait dengan keberimbangan dapat ditunjukkan dengan penggunaan sumber berita. Berita menjadi berimbang ketika jurnalis memberitakan suatu kejadian atau konflik dengan mengangkat lebih dari satu sumber pihak yang terlibat. Hal ini terkait erat dengan adanya sudut pandang yang berbeda yang direfleksikan dalam suatu pemberitaan dan penyajian dua sisi cerita (atau lebih) di mana penilaian khalayak atas fakta-fakta dapat dilawankan. Keberimbangan juga berarti memastikan kesamaan atau keseimbangan proporsi waktu, tempat, penekanan dalam memberitakan oposisi interpretasi, sudut pandang atau kejadian. (McQuail, 2009).

Menyajikan satu sumber berita berarti hanya menyajikan satu sisi cerita dalam memberitakan kejadian maupun konflik. Sedangkan dengan menyajikan lebih dari satu sumber berita yang terkait dengan kejadian yang diberitakan.

Hasil penelitian memerlihatkan bahwa $59,3 \%$ berita di VOA-Islam disajikan dengan hanya satu sumber berita saja. Ini artinya lebih dari setengah jumlah berita yang dimunculkan dalam situs berita ini belum bisa dikatakan berimbang dalam pemberitaan. Sejauh pengamatan peneliti, banyak beritaberita sepihak ini hanya menggunakan sumber berita dari para ulama maupun ustaz utamanya yang sering muncul adalah dari sumber Ormas FPI (Front Pembela Islam). Perlu diketahui, peneliti juga telah menjelaskan di awal tulisan ini, bahwa Ahok adalah tokoh yang sangat bersemangat dengan agenda pembubaran FPI, khususnya di DKI Jakarta. Oleh sebab itu, dalam konflik ini hanya satu pihak saja yang dijadikan sumber pemberitaan, berita yang disiarkan tampak sepihak bahkan di beberapa berita cenderung sangat kasar dan menjatuhkan. Seperti salah satu berita berjudul "Ahok Ingin Bubarkan FPI, Pemimpin Angkuh akan Tumbang dengan Kehinaan", judul berita tersebut cenderung kasar dan menjatuhkan karena hanya berisi pendapat dari hasil wawancara dengah salah satu tokoh FPI.

Pada kategori sumber berita ini, juga didapat 22 berita atau $40,7 \%$ dari populasi berita menggunakan lebih dari satu sumber berita. Namun berita ini masih belum bisa 
disimpulkan berimbang, karena keberimbangan juga ditentukan dari kategori

\section{Tabel 1}

Kategori Evaluative Tendency

\begin{tabular}{ccc}
\hline & Frekuensi & Persen \\
\hline Positif & 1 & 1,9 \\
Negatif & 44 & 81,5 \\
Netral & 9 & 16,7 \\
Total & 54 & 100,0 \\
\hline
\end{tabular}

Sumber: Hasil Penelitian

lain salah satunya proporsi penyajian sumber berita.

Proporsi sebanding adalah ketika dalam satu berita disajikan lebih dari satu sisi cerita dengan porsi sebanding, yang akan dilihat dari perbandingan panjang paragraf dalam sebuah berita tentang Gubernur DKI Jakarta. Proporsi tidak sebanding adalah ketika berita menyajikan dua sisi cerita namun lebih banyak menceritakan satu sisi saja, dan hal tersebut ditunjukkan dengan panjang paragraf yang perbedaannya lebih dari 1:2. Sedangkan berita yang tidak menyajikan dua sisi cerita akan dimasukkan dalam kategori ketiga yaitu tidak ada proporsi sama sekali, dalam tabel 2 (dua) di atas terlihat sebanyak 32 berita atau sebanyak $59,2 \%$ berita masuk pada jenis ini.

Pada kategori proporsi penyajian berita, terdapat 22 berita yang terbagi dalam dua jenis yaitu 7 (tujuh) berita dengan proporsi penyajian sumber berita sebanding dan 15 berita proporsinya tidak sebanding. Dari kedua kategori ini saja (sumber berita dan proporsi penyajian) sudah terlihat bahwa sebagian besar berita dari VOA-Islam berada pada porsi tidak berimbang.

Tidak ada sudut pandang baru berarti sebuah berita mengenai Basuki Tjahaja Purnama alias Ahok, hanya menyediakan satu sudut pandang untuk menilai kejadian yang diberitakan tersebut. Berbeda dengan berita yang dianggap memunyai sudut pandang baru atau sudut pandang alternatif. Berarti sebuah berita menawarkan sudut pandang yang berbeda dalam satu berita, atau bisa jadi satu berita merujuk pada pemberitaan sebelumnya dengan menawarkan sudut pandang alternatif. Pada intinya berita dikatakan bersudut pandang baru jika berita tersebut memberi ruang pada khalayak untuk menilai kejadian dari beberapa sudut pandang.
Namun dari populasi berita VOA-Islam yang memberitakan Ahok, hanya 7 (tujuh) berita dari 54 berita atau sekitar $13 \%$ berita saja yang memberikan ruang pada pembaca untuk menilai kejadian dari beberapa sudut pandang. Sisanya, sebanyak $87 \%$ berita hanya menyajikan satu sudut pandang saja. Hal ini berkaitan dengan banyaknya berita yang hanya menggunakan satu sumber berita saja. Dari berita-berita yang disajikan, cenderung memojokkan sosok Gubernur DKI Jakarta ini karena hanya menyajikan sudut pandang dari sisi lawan konfliknya dari setiap peristiwa.

Tendensi atau kecenderungan arah berita dikatakan negatif ketika inti berita didominasi keburukan dari tokoh yang diberitakan, dalam hal ini Ahok, di luar ada tidaknya sumber berita/sisi cerita/sudut pandang kedua. Jika sebuah headline sudah mengarah pada sisi negatif, misalkan pelanggaran atau bentrokan simpatisan, maka topik berita tersebut cenderung mengarah pada sisi negatif dari kampanye simpatisan parpol. Sedangkan kecenderungan mengarah pada sisi positif ketika inti berita tentang Ahok tidak berkaitan dengan sisi-sisi buruk seperti pelanggaran, bentrokan, konflik, atau unsur negatif lainnya, dan lebih mengarah pada sisi positif misalnya ketertiban, keamanan, atau perdamaian. Selain itu ada juga berita yang termasuk cenderung netral jika tidak memuat sisi negatif maupun positif dari pemberitaan secara dominan.

Menariknya, dalam tabel 1 (satu) muncul angka yang cukup tajam perbedaanya. Hanya 1 (satu) berita yang cenderung positif, atau hanya $1,9 \%$ dari seluruh populasi berita. Berita ini adalah berita berjudul "Ahok Tegaskan Gubernur dan Wagub DKI Jakarta Dukung Densus 88" yang dimuat pada 23 Mei 2013. Dari berita 
tersebut, sumber berita satu-satunya adalah dari Ahok yang menyatakan DKI Jakarta mendukung Densus 88. Yang cukup mengagetkan di sini adalah hasil yang menyatakan 44 berita dari 54 berita memiliki tendensi atau kecenderungan arah berita dikatakan negatif. Artinya $81,5 \%$ berita tentang Ahok, mendiskreditkan ahok sebagai tokoh penting di DKI Jakarta. Penyajian dengan hanya satu sumber berita, kalaupun ada lebih dari satu sumber proporsinya tidak sebanding, juga sudut pandang tunggal memunyai andil yang besar dalam memasukkan berita ke dalam tendensi negatif. Selain itu, opini dari pembuat berita yang dominan dan cenderung berpihak juga menjadi salah satu faktor banyaknya berita bertendensi negatif.

\section{Relevansi (Relevance)}

Secara sederhana, faktualitas adalah bagaimana berita menceritakan dunia nyata pada khalayak. Salah satu dimensi faktualitas adalah relevansi, terkait seberapa banyak informasi yang perlu dan penting untuk diketahui oleh masyarakat. Relevansi di sini lebih terkait dengan proses seleksi dibanding presentasi. Relevansi membutuhkan proses seleksi yang jelas dan koheren dengan apa yang dianggap signifikan oleh khalayak atau masyarakat pada umumnya. Kriteria relevansi memang bisa berbeda jika dilihat secara teori, sudut pandang jurnalis dan sudut pandang khalayak. Akan tetapi menurut teori yang lebih objektif, relevansi terkait dengan apa yang menjadi signifikan dalam perspektif historis jangka panjang dan apa yang dapat memberi kontribusi bagi masyarakat. Maka berita yang menyangkut karakter personal, human interest, olahraga, dan hiburan tidak dikategorikan ke dalam relevansi.

Burgoon dalam McQuail

mengatakan bahwa relevansi dapat dibedakan menjadi signifikansi dan interest (minat); yang pertama terkait dengan hal-hal yang memengaruhi kehidupan orang banyak, yang kedua terkait dengan isu yang menarik dan tak biasa, yang ketiga terkait kedekatan dengan masyarakat, ketepatan waktu dan kejadian berskala besar. Kedekatan yang dimaksud Burgoon adalah perihal apakah topik berita yang disajikan dekat dengan aktivitas kehidupan masyarakat sehari-hari. Peneliti juga lebih condong pada penggunaan indikator signifikansi McQuail dan Burgoon yaitu dapat memengaruhi kehidupan orang banyak, bukan pada poin yang terkait dengan interest karena interest lebih bersifat personal.

Berita dikategorikan signifikan ketika berita tersebut memiliki pengaruh terhadap aktivitas dan kehidupan masyarakat. Ketika sebuah berita melaporkan kesalahan yang dilakukan oleh Ahok dengan menyertakan informasi fakta kesalahan apa saja yang dilakukan dan apa yang seharusnya, berita ini dapat menjadi informasi bagi masyarakat khususnya pejabat daerah lain untuk lebih waspada dalam menjalankan tugasnya. Sedangkan berita dikategorikan tidak signifikan ketika berita tersebut semata-mata memberitakan siapa saja artis ibukota yang mengisi acara kampanye parpol untuk menghibur para simpatisan. Pada kerangka teori sudah dijelaskan peneliti menggunakan definisi McQuail (2005) bahwa berita terkait hiburan dan interest tidak termasuk dalam poin relevansi.

Dalam kategori signifikansi, tampak bahwa $61,1 \%$ berita memasukkan unsur memengaruhi aktivitas hidup masyarakat. Ini artinya banyak berita yang tidak hanya menyajikan kejadian namun juga menyajikan informasi pelengkapnya yang memengaruhi khalayak pembacanya, berita tersebut bisa dikategorikan bertendensi negatif. Hasil ini tentu memengaruhi apa yang didapat dikategori signifikansi. Jadi kemungkinan signifikan pengaruh yang disajikan oleh VOA-Islam ini termasuk bertendensi negatif juga besar.

Berita dikatakan memiliki kontribusi terhadap masyarakat ketika berita tersebut memuat informasi yang berguna menambah pengetahuan bagi masyarakat. Berita penolakan pembubaran FPI dikatakan 
Tabel 2

Kategori Konten SARA

\begin{tabular}{ccc}
\hline & Frekuensi & Persen \\
\hline Ada konten bermuatan SARA & 39 & 72,2 \\
Tidak ada konten bermuatan SARA & 15 & 27,8 \\
Total & 54 & 100,0 \\
\hline
\end{tabular}

Sumber: Hasil Penelitian

memiliki informasi yang berguna ketika menyebutkan peraturan apa saja yang melindungi FPI atau data yang menyatakan peran positif ormas Islam dalam masyarakat. Kontribusi berita ini adalah menambah pengetahuan masyarakat peran ormas Islam secara umum maupun mengenai FPI secara khusus. Sedang berita dikatakan kecil kontribusinya bagi masyarakat ketika informasi yang diberitakan sifatnya trivia (sepele atau hiburan). Misalnya berita yang melaporkan asisten pribadi Ahok yang tidak masuk kerja atau Istri Ahok yang sering berbelanja di mall sifatnya cenderung trivia dan bukan informasi yang besar gunanya bagi masyarakat umum.

Dalam kategori kontribusi bahwa 39 berita dari 54 berita sifatnya hanya informasi trivia, tidak menambah pengetahuan. Berita yang informasinya remeh temeh, maupun opini tokoh yang tidak disertakan data maupun fakta pendukung. Kecenderunganya $72,2 \%$ berita hanya mengangkat hal yang sebenarnya kecil dan tidak menambah pengetahuan namun cenderung memojokkan Ahok selaku Gubernur DKI Jakarta (ingat tendensi negatif sebesar 81,5\%). Sedangkan berita yang menambah pengetahuan sebesar $27,8 \%$ atau sebanyak 15 berita dari 54 berita (lihat tabel 2). Berita ini biasanya ditambahkan informasi yang diambil dari kitab suci AlQuran atau berdasar pada hadis Nabi.

Dilihat dari kedekatan topiknya, berita dapat dikategorikan ke dalam berita yang topiknya berhubungan dengan aktivitas dan kehidupan masyarakat. Berita konflik atau bentrokan antarkelompok/golongan terkait dengan Ahok dianggap berhubungan dekat dengan jalannya aktivitas dan kehidupan masyarakat. Sedangkan berita yang topiknya tidak ada kedekatan atau tak terlalu berhubungan dengan masyarakat dikatakan tidak terlalu relevan. Berita mengenai pemikiran ataupun pandangan ormas tertentu termasuk dalam kategori ini. Berita ini hanya berhubungan dengan topik Ahok tapi tidak menyentuh sisi kehidupan masyarakat.

Hasil penelitian menunjukkan 37 berita dari 54 berita berhubungan dengan aktivitas hidup masyarakat. Ini artinya $68,5 \%$ berita adalah berita yang sangat dekat dengan kehidupan masyarakat banyak. Masyarakat membutuhkan informasi yang disajikan dalam berita VOA-Islam karena kedekatanya. Namun temuan tentang ketidakberimbangan penyajian berita khususnya besarnya persentase berita dengan tendensi negatif membuat peneliti merasa cemas hasil ini. $68,5 \%$ berita di VOA-Islam adalah berita yang dibutuhkan masyarakat berkaitan dengan kedekatanya, namun konten berita yang tidak berimbang dan cenderung negatif sudah seharusnya perlu dikhawatirkan.

VOA-Islam adalah situs berita online berlandaskan agama, oleh sebab itu peneliti menganggap perlu untuk memastikan bahwa isu sensitif ini tidak disalahgunakan peranannya untuk menjatuhkan tokoh Ahok yang notabene sebagai Cina (non pribumi) dan juga non muslim.

Hasil penelitian menunjukkan, 39 berita dari 54 berita yang disajikan situs berita ini terbukti bermuatan SARA. Muatan isu SARA yang cenderung negative, dikhawatirkan akan memecah belah persatuan bangsa ini. $72,2 \%$ berita bermuatan SARA ini sebagian besar berisi penyebutan Ahok sebagai Cina dan Kafir (tidak beragama) ataupun keduanya. Etnis Cina diposisikan sebagai kaum pendatang yang seharusnya minoritas namun nyatanya menguasai perekonomian dan pemerintahan (khususnya di Jakarta), dan penyebutan kafir yang memiliki posisi sangat rendah dan hina di mata manusia karena tidak memiliki Tuhan. Padahal negeri ini adalah 
negeri berbinekatunggalika yang mengakui perbedaan suku dan agama, namun hal itu sepertinya tidak dipedulika oleh VOA-Islam. Hanya $27,8 \%$ berita yang bebas dari konten bermuatan SARA, nilai ini sangat kecil.

Dunia maya ini telah membanjiri masyarakat dengan informasi. Dengan pemahaman yang rendah tentang fenomena ini, bisa saja masayarakat akan hanyut, tersesat dan mungkin kehilangan jati diri dialam banjir informasi ini. DiMaggio, et al. (2001) telah mempelajari sejarah perkembangan internet dan betapa besar pengaruh lahirnya internet ini bagi kehidupan masyarakat. Tidak hanya membawa perubahan positif, interet juga membawa pengaruh negatif. Mungkin menyamakan internet dengan tajamnya mata pisau adalah hal yang bijak, pisau yang tajam selain bisa membantu pekerjaan manusia, juga bisa membunuhnya.

Seperti peran internet sebagai jendela informasi. Disana bertabur berjuta informasi yang dibutuhkan manusia, namun Kovach dan Rosenstiel (2011) mengingatkan jika tidak pandai memilih informasi akan membawa manusia kepada ketersesatan. Buktinya adalah salah satu penyedia informasi di internet yang menamakan dirinya VOA-Islam ternyata termasuk dalam kategori beresiko konten muatanya. Teori konvergensi menyatakan bahwa berbagai perkembangan bentuk media massa terus merentang dari sejak awal siklus penemuannya (Stovall, 2005). Meski media massa online tidak dapat menggantikan peran media massa konvensional/tradisional, namun perannya kini cukup besar dalam kehidupan masyarakat.

\section{PENUTUP}

\section{Simpulan}

Dimensi keberimbangan dari situs berita VOA-Islam cenderung kecil, artinya menunjukkan keberpihakan. Hanya kurang dari setengah dari jumlah berita yang diteliti yang menggunakan lebih dari satu sumber berita, itupun dengan presentasi proporsi berita yang sebanding lebih kecil dari yang tidak sebanding. Bahkan sebagian besar beritanya hanya menyajikan satu sudut pandang saja, yang artinya pembaca tidak diberi ruang untuk melihat sudut pandang lainya. Pembaca akan digiring mengikuti arah pemikiran produsen berita. Dari temuan itu semua yang membuat muatan berita dari VOA-Islam bertendensi negatif terhadap objek pemberitaanya. Artinya konten beritanya cukup subjektif dan menjelekjelekkan objek pemberitaanya (dalam penelitian ini Basuki Tjahaja Purnama alias Ahok yang menjadi objek pemberitaan).

Ketidak-berimbangan

dalam pemberitaan yang dilakukan VOA-Islam memengaruhi dimensi relevansi. Seperti pada kategori signifikansi, terlihat bahwa lebih dari setengah dari jumlah berita yang diteliti memasukkan unsur memengaruhi aktivitas hidup masyarakat. Ini artinya banyak berita yang tidak hanya menyajikan kejadian namun juga menyajikan informasi pelengkapnya yang memengaruhi khalayak pembacanya. Namun sayangnya, temuan pada kategori keberimbangan menyatakan sebagian besar berita bertendensi negatif. Hasil ini tentu memengaruhi apa yang didapat dikategori signifikansi.

Pengujian terakhir yang dilakukan peneliti pada kategori konten bermuatan isu SARA mendapat hasil yang memprihatinkan. Banyak berita yang disajikan situs berita ini terbukti bermuatan SARA dan jika mempertimbangkan konten muatan bertendensi negatif yang juga besar, maka situs berita ini cukup riskan karena berpeluang besar memancing perpecahan bahkan konflik atas nama SARA.

Nilai keberimbangan yang rendah dan negatif, ditambah dengan nilai relevansi yang tinggi dalam memengaruhi masyarakat membuat peneliti menyimpulkan bahwa situs ini berdampak negatif terhadap pembacanya secara khusus dan masyarakat pada umumnya. Apalagi jika melihat dominasi konten-konten bermuatan SARA yang ada di dalamnya, situs berita yang sepihak ini berpotensi besar memecah persatuan bangsa 
ini yang terdiri dari beragam suku, ras, dan agama.

\section{Saran}

Kementerian Komunikasi dan Informatika hendaknya, mulai bergerak cepat dalam menangani fenomena ini. Dibutuhkan regulasi yang tepat untuk menekan jumlah situs-situs berita yang dikhawatirkan akan memicu perpecahan di negeri ini. Selain itu, masyarakat juga sebaiknya menjadi lebih cerdas memilih sumber informasi di tengah banjir informasi ini.

\section{DAFTAR PUSTAKA}

\section{Buku:}

Bungin, B. (2006). Sosiologi Komunikasi. Jakarta: Erlangga.

Djuroto, T. (2002). Menulis Artikel dan Karya Ilmiah. Bandung: Remaja Rosdakarya.

Foust, J. (2009). Online Journalism Principles and Practices of News for the Web, 2nd ed. Arizona: Holcomb Hathaway Publisher.

Ishwara, L. (2005). Catatan-Catatan Jurnalisme Dasar. Jakarta: Penerbit Buku Kompas.

Kovach, B. dan Rosenstiel, T. (2011). Blur: How to Know What's True in the Age of Information Overload, New York: Bloomsbury.

Kriyantono, R. (2006). Teknis Praktis Riset Komunikasi. Jakarta: Kencana.

Kusumaningrat, H. (2007). Jurnalistik Teori dan Praktek. Bandung: Remaja Rosdakarya.

McQuail, D. (1989). Teori Komunikasi Massa: Suatu Pengantar (terjemahan). Jakarta: Erlangga. ---. (1994). Fungsi Media. Jakarta: Erlangga.
---------. (2009). Mass Communication Theory: 6th Edition. London: Sage Publication.

Panuju, R. (2005). Nalar Jurnalistik: DasarDasar Jurnalistik. Malang: Bayumedia.

Pavlik, J. (2001). Journalism and New Media. Columbia: Columbia University Press.

Prajarto, Y. A. N. (2010). Analisis isi Metode Penelitian Komunikasi. Yogyakarta: FISIPOL UGM.

Santana, S. (2005). Jurnalisme Kontemporer. Jakarta: Yayasan Obor Indonesia.

Sobur, A. (2004). Analisis Teks Media: Suatu Pengantar Untuk Analisis Wacana, Analisis Semiotik, dan Analisis Framing. Bandung: Remaja Rosdakarya.

Sumadiria, H. (2005). Jurnalistik Indonesia: Menulis Berita dan Feature. Bandung: SRM.

\section{Jurnal:}

DiMaggio, P., Hatgittai, E., Neuman, W. R. dan Robinson, J. P. (2001). Sosial Implication of the Internet. Annual Reviews, hal. 307-336.

Stovall, D. (2005). Engaging community: Notes on the necessity of reflection. Journal of Thought, hal. 55-66.

Westerstahl, J. (1983). Objective News Reporting. Communication Research, hal. 403-424.

\section{Tesis:}

Pitoyo, A. Z. (2007). Analisis Isi Situs Web Tanggap Bencana Alam Gempa Bumi D.I.Yogyakarta dan Jawa Tengah. Tesis, Univesitas Gadjah Mada.

\section{Internet:}

Snelson, C. (2005). Sampling the Web: The Development of a Custom Search Tool for Research [internet], Boise State University. Tersedia dalam: $<$ http://libres-ejournal.info/wpcontent/uploads/2014/06/Vol16_I1_Sne lson.pdf> [diakses 2210 2014]. 